\title{
BORDER GUARDS' COMPETENCE IN ENGLISH PROFESSIONAL TERMINOLOGY: CHALLENGES AND POSSIBLE SOLUTIONS
}

\author{
Marina Žukova \\ Mg. paed., Docent of General Subjects Department of the State Border Guard \\ College, e-mail: marina.zukova@rs.gov.lv, Rēzekne, Latvia
}

\begin{abstract}
Knowledge of English professional terminology is one of the predominant factors for border guards' successful professional performance during both border and immigration control carried out at their national state border and inside the country and also joint operations organised and implemented by the European Border and Coast Guard at the EU external borders. The present article suggests an overview of the results of the measures taken by the State Border Guard of Latvia in 2017-2020 to facilitate the improvement of Latvian border guards' competence in English professional terminology. Based on the results of the survey the author puts forward suggestions for possible improvements in English language training and testing for border guards.
\end{abstract}

Keywords: assessment, English professional terminology, examinations, levels, quality, requirements, tests.

\section{Introduction}

Communication, which is described in one of its definitions given by Davis as "a bridge of meaning among people so that they can share what they feel and know," (Chaturvedi, 2011, p.8) is an integral part of border guards' work, especially those who fulfil their service tasks at border crossing points at the European Union (the EU) external border and in Immigration Service inside the territory of their country.

Being the ones, whose primary task is to check the legality of border crossing, they have to be ready to ask questions and provide clarifications to their customers to ensure efficient application of border crossing regulations and fulfilment of conditions for legal residence and stay in their country laid down for the EU and third-countries nationals. Thus the knowledge of foreign languages, and English in particular, becomes of crucial importance. English as one of the most widely used means of communication between people of different nationalities often helps border guards and travellers interact and reach understanding.

The importance of foreign language knowledge for the EU border guards is emphasised in several normative acts. The Article 16 of the EU Regulation 2016/399 of the European Parliament and of the Council of 9 March 2016 on a Union Code on the rules governing the movement of persons across borders (Schengen Borders Code) includes the provision that "Member States shall ensure that the border guards are specialised and 
properly trained professionals, taking into account common core curricula for border guards established and developed by the European Agency for the Management of Operational Cooperation at the External Borders of the Member States (the Agency) established by Regulation (EC) No 2007/2004. Training curricula shall include specialised training for detecting and dealing with situations involving vulnerable persons, such as unaccompanied minors and victims of trafficking. Member States, with the support of the Agency, shall encourage border guards to learn the languages necessary for the carrying-out of their tasks".

The "Common Core Curriculum for Border and Coast Guard Basic Training in the EU" (CCC, 2017) offers minimum standards for basic level border and coast guards training which should be implemented by national border and coasts guards training institutions and defines that "apart from performing their tasks and duties in their national language, border and coast guards must also prove their proficiency in English, the EU official language, in order to be able to serve all the persons involved in regular or irregular border crossing and also to cooperate with their foreign counterparts in joint operations" (p.48). In addition it is mentioned in the CCC that the threshold foreign language proficiency of the CCC refers to B1 level of the Common European Framework of Reference for Languages (CEFR).

The present article is a survey on the actions taken by the State Border Guard of Latvia (SBG) in order to facilitate improvement of the knowledge of English professional terminology for their officials.

The research carried out in the period from January 2017 until July 2020 included several stages: development of SBG internal rules regarding the level of knowledge of English professional terminology for the SBG officials (January 2017- October 2018), development of tests in Border Guard English professional terminology (December 2018-April 2019), implementation of examinations (April 2019-January 2020) and analysis of the results of examinations (January- July 2020).

The author offers an overview of the requirements regarding the knowledge of English professional terminology set by the SBG to different categories of border guards, as well as analyses the results of examinations in professional terminology for border guards and puts forward suggestions for improving English language training and examinations systems for border guards in Latvia.

\section{Overview of the research}

Being aware of the importance of improvement of English language knowledge for border guards serving at the EU external border (the results 
of the testing carried out in the State Border Guard in 2013 showed that border guards' level of English was not very high - 55\% of border guards had a very limited knowledge of professional terminology) the SBG delegated the language teachers of the State Border Guard College (SBGC) to ensure the implementation of a number of measures to provide its personnel with the opportunity to increase their foreign language proficiency, as well as assess their level of knowledge of English professional terminology:

- development of SBG internal rules describing the procedures for acquisition, maintenance and control of the knowledge of English professional terminology (the SBG rules) for the officers of the SBG;

- development of on-line tests to assess the border guards' knowledge of English professional terminology according to the levels defined in the SBG rules (December 2018- April 2019);

- implementation of examinations (April 2019- January 2020).

The SBG rules, which came into force in October are binding on border guards who carry out border checks, border surveillance and immigration control, as well as participate in joint operations at the EU external borders implemented by Frontex, the European Border and Coast Guard Agency (Frontex).

Considering the level of responsibility and amount of information the SBG officials are expected to be able to give in English to persons crossing the state border, the following levels of the knowledge of professional terminology were defined:

- Level 1 (for SBG senior officers usually holding the positions of chiefs and deputy chiefs of the SBG units and all border guards who participate in Frontex joint operations regardless their positions);

- Level 2 (for SBG junior officers usually holding the positions of senior inspectors and the ones involved in second line checks);

- Level 3 (for SBG instructors carrying out first line checks).

The levels descriptors were developed based on the study of the peculiarities of service tasks and responsibilities of the SBG officials belonging to the specified categories, recommendations regarding border and coats guards' English proficiency included in the CCC and the guidelines in CEFR:

- Level 1

Officer is able to:

- use English professional terminology;

- discuss freely the topical issues related to professional area without prior preparation;

- produce freely monologue and dialogue speech;

- choose speaking style (formal/informal) relevant for situation; 
- participate in discussions, to justify their opinion in order to communicate efficiently in multinational environment;

- produce clear narration, by using appropriate arguments, emphasising particular issues and making conclusions;

- prepare and make a thematic presentation in professional area;

- communicate with foreign colleague by different means of communication (telephone, e-mail, correspondence);

- write letters, e-mail messages, CV and reports in English.

Officer has a wide vocabulary to avoid repetition, can stably maintain a high level of grammatical correctness, is able to independently correct mistakes.

- Level 2

Officer is able to:

- provide information about the SBG, its structure and functions, as well as a detailed information about their duties;

- use professional terminology to check travel, vehicle and vessels documents, visas and documents which justify the purpose of entry and residence, as well as rights to be employed;

- use professional terminology to ensure profiling, interviewing and identifying persons while carrying out second line check;

- give instructions to travellers and explain different procedures (refusal of entry, drawing up administrative violation reports, imposing administrative sanctions, procedure of appealing against the decision);

- use professional terminology to ensure acceptance of an asylum seeker's application for refugee or alternative status;

- use professional terminology to communicate with detained persons, as well as ensure return procedures;

- write letters and e-mails in English;

- speak freely and maintain conversation without searching for words;

- start, maintain and close conversation;

- produce clear, detailed text on a wide range of subjects and explain a viewpoint;

Officer demonstrates a relatively high degree of grammatical control and possesses a high lexical accuracy, in some cases, inaccurate word choices do not interfere with communication. Sometimes minor mistakes are made.

\section{- Level 3}

Officer is able to: 
- give general information about themselves (name, surname, service rank, basic tasks) and their structural unit (name, location, main tasks and basic activities;

- describe border check procedures done in their unit;

- understand information in identity documents, vehicles and vessels documents;

- use professional terminology while performing their service duties in their unit (interviewing persons during first line check, immigration control, detaining persons) within the competence of a junior inspector and inspector;

- use professional terminology in problem situations (traveller's document is not valid, traveller does not have a document, person asks for asylum, giving first aid, person does not obey border guard) within the competence of a junior inspector and inspector;

- understand the main points of clear standard speech on familiar matters, perceive both general information and details, can understand the information in general if the topic is familiar, the presentation is simple and clearly structured;

- communicate about familiar topics, exchange, check and/or approve information.

Officer has sufficient vocabulary to communicate in predictable situations, demonstrates a good control of grammar, although the influence of the mother tongue is noticeable. Mistakes do not interfere with the communication process.

According to the SBG rules the SBG officers:

- acquire the knowledge of English professional terminology in the English professional terminology courses within the formal and non-formal education programmes implemented by the SBGC and Rezekne Academy of Technologies;

- maintain their knowledge by using training materials and resources produced by the language teachers of the SBGC and Frontex;

- on successful completion of corresponding training courses receive certificates which prove their level according to the SBG rules;

- are obliged to pass the first examination to prove their level within two years after the rules come into force and subsequent examinations every five years. Officers are allowed to repass the examination two times. If a border guard does not success the chief will have to evaluate if their competence is adequate to the position.

Based on the SBG rules all officers to whom they are binding are obliged to pass examinations according to the level they are expected to reach in order to fulfil their daily tasks successfully. The examinations were developed by the English language teachers of the SBGC. Each of them 
consisted of two parts - an on-line test, placed in SBGC e-learning system based on the Moodle platform, to check the knowledge of relevant vocabulary, grammatical proficiency, listening and reading skills and an oral test to check speaking skills including the ability to give a professional presentation and use the professional terminology in regular and irregular border crossing situations in accordance with the levels descriptors in the SBG rules.

The results of the examinations in the present article are interpreted based on the assessment scale developed by the authors with the following grades: $10-40 \%$ (failing), $50 \%$ (satisfactory), which is the lowest passing grade, $60-70 \%$ (good), $80-90 \%$ (very good) and 100\% (excellent).

The author suggests a review of the results of the examinations implemented in the period from April 2019 until January 2020.

482 border guards participated in the examinations during the above mentioned period - 195 members of the European Border and Coast Guard Team (EBGCT), who regularly participate in Frontex joint operations passed the examination for Level 1 and 287 other border guards involved in border checks, border surveillance and immigration control on the Latvian state border, 64 of which passed the examination for Level 2 and 223 - for Level 3.

According to the overall results of the examinations presented in figure 1 the majority of the examinees, that is $87 \%$ have successfully completed all the tasks - 44\% (214 border guards) demonstrated good knowledge of professional terminology, 20\% (96 border guards) satisfactory and 23\% (109 border guards) very good knowledge of professional terminology, while 13\% (63 border guards) failed the examinations.

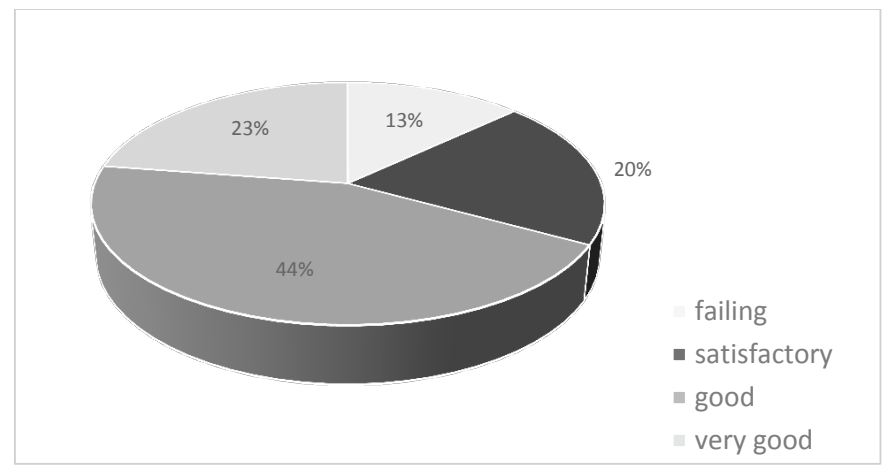

Figure 1. Results of examinations in English professional terminology (created by the author) 
A deeper analysis of the results allows to conclude that better results were achieved by EBGCT members: 40,5 \% of which demonstrated very good knowledge, $50 \%$ - good and 6,6\% - satisfactory knowledge of professional terminology and only $2,9 \%$ - failed the test. At the same time $28 \%$ of border guards holding junior officers positions failed the examination, $20 \%$ - demonstrated satisfactory knowledge of professional terminology, $40,7 \%$ - good and $11,3 \%$ - very good knowledge of professional terminology. $10,4 \%$ of border guards holding inspectors positions proved to have very good knowledge, 40,9\% - good, 31,4 satisfactory knowledge of professional terminology and 17,3\% failed.

The obvious differences in the numbers of those who passed and failed the examinations between the border guards belonging to the three categories of positions mentioned in the SBG rules can be explained by the fact that the ones who belong to EBGCT and regularly participate in Frontex joint operations in other EU member states are more motivated to maintain and improve their level of knowledge of both general English and English professional terminology. They realize the added value of this particular kind of knowledge and skills in building their professional competence as they get into circumstances when there is a need to use English for communication with travellers, migrants or their foreign colleagues more often than their Latvian colleagues who perform their service duties mostly in their native country and use their foreign language knowledge rather seldom due to a comparatively low number of travellers at the Latvian state border who use English as a medium of communication.

The number of failures is bigger among the border guards holding junior officers positions .The possible reasons for that, in the author's opinion, could be the lack of communication in English (the majority of participants from this category work in border surveillance units located on the border of Latvia with the Russian Federation and the Republic of Belarus and the situations when they need to use English are not very common) and absence of preliminary English language training together with the lack of motivation both inner and external to learn the foreign language. The bigger part of the border guards who failed the examinations received their Border Guard education in early 2000-s, when students in schools could choose to learn one of the two foreign languages- English or German. Both the languages were of equal importance in the society at that time. Thus while studying in the secondary school and in the SBGC they learned the German language and professional terminology in German accordingly. After the change of the position of English in Latvia, when it became the obligatory subject taught in secondary schools starting with the first form, German lost its importance, it was no longer considered relevant to border guarding and was removed from the Border Guard educational 
programmes. In the result border guards who learned German somehow stayed out of the system. The institution did not offer them to learn English. The target audience of the English qualification courses provided by the SBG were the border guards who had preliminary general English knowledge. Thus the border guards who learned German, due to the specifics of their service places - the border surveillance units and border crossing points on the Latvian border with the Russian Federation and the Republic of Bearus, where communication with travellers happens mostly by means of Russian, did not see any profit to acquire the language themselves, to pay for the courses to get the knowledge which is not applicable in their daily work.

Figure 2 demonstrates the results in each of the parts of the examination - on-line test and speaking test.

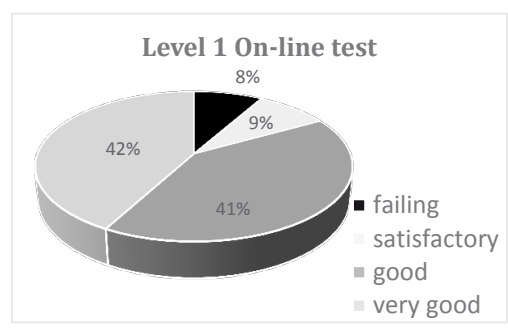

Level 2 On-line test

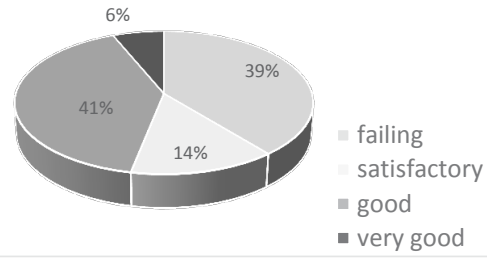

Level 3 On-line test

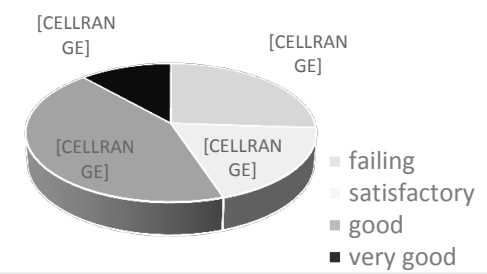

Level 1 Speaking test

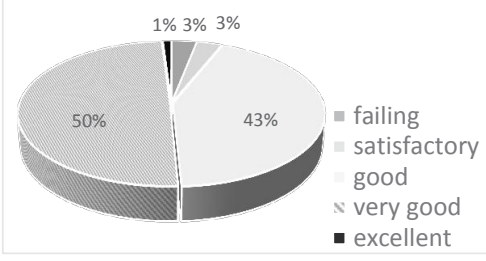

Level 2 Speaking test

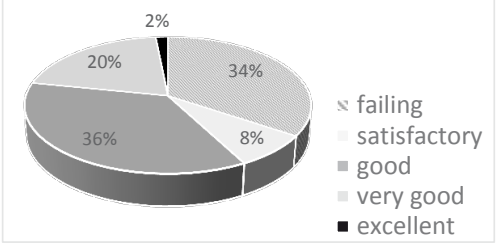

Level 3 Speaking test

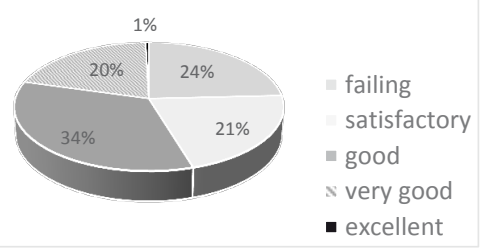

Figure 2. Results in on-line and speaking tests for Level 1, Level 2 and Level 3 (created by the author) 
In author's opinion the data in figure 2 can serve as a basis for the following conclusions:

- the proportions of successful results in both tests are equal for each of the levels, which allows to assume that the results of the examinations are credible and provide a realistic overview of the examinees scope of knowledge and skills. There is a direct connection between the language users' speaking skills and lexical and grammatical proficiency, reading and listening skills, the border guards who have poor vocabulary and grammatical proficiency can hardly demonstrate high results in speaking tasks;

- the number of failures in both parts of the examinations is bigger among border guards who have passed the examinations for Level 2 and Level 3, the author described the possible reasons for that above.

\section{Conclusions and suggestions}

Based on the results of the analysis of the activities implemented during the research and the research findings the author comes to the following conclusions:

1. The results of examinations implemented in the course of the research are indicative of obvious overall improvement of border guards' level of knowledge of English professional terminology (in 2013 only $45 \%$ of examinees passed the test successfully, in 2019-2020 - the indicator reached $87 \%$ ).

2. The level of knowledge of a foreign language and professional terminology is directly related to border guards' inner and external motivation, work needs and the level of general English they have when join the SBG. The more often they encounter the situations when they benefit from communication in English, the higher their motivation to learn English and improve the knowledge is.

3. The present requirements regarding the border guards' knowledge of English are not optimal and do not fully correspond to the real situation and needs in the structural units, which causes negative attitude to the language examinations and language learning itself.

4. The SBD delegated task to develop the SBG rules, on-line tests and implement the examinations caused a considerable increase in the workload of English language teachers of the SBGC, who along with the implementation of language training within formal and non-formal 
education programmes are involved both in development of Border Guard specific training materials and resources and, being SBG officers, do other tasks delegated by the administration of the SBGC. Inadequate amount of tasks together with a relatively short period of time given for the organisation of examinations and Covid-19 spreading in the world in spring 2020 were the main reasons why the teachers succeeded to organise examinations only for $48 \%$ of the initially planned number of border guards.

5. Teachers who developed the tests have a lack of knowledge about the peculiarities of creating on-line tasks in Moodle platform, which resulted in some malfunctions of the test, in several cases examinees' performance was not adequately assessed due to inaccuracies or errors in the encodings of questions and answers. The support from specialist was needed to eliminate shortcomings.

6. The teachers encountered difficulties in organising examinations for the officers serving in the SBG units located far from the SBGC. Their participation in the examination caused additional financial expenses due to the need to cover the costs of transportation and daily subsistence and complications in planning personnel work schedules due to the lack of staff.

To improve the English language training and examinations systems in the SBG the author puts forward the following suggestions:

1. In order to get a more comprehensive picture of the officers levels of knowledge of English professional terminology in accordance with the SBG rules it is necessary to prolong the period of examinations at least for 1 year and test as many border guards as possible.

2. The SBG should reconsider the categories of border guards, who based on the SBG rules, are required to reach certain level of knowledge of English professional terminology, and to make a careful assessment of English language needs for the border guards working in border surveillance units.

3. The SBG should evaluate the possibility to set up computer classrooms in SBG territorial boards. The use of such classrooms could considerably save time and financial resources, ease the staff planning process and make it possible to organise distance English language examinations for border guards working in the units located at long distances from the SBGC, consisting of on-line tests and interviews in video conferencing modes. The computer classroom could be used also for implementing other e-learning qualification improvement programmes, which are becoming more and more popular.

4. In order to motivate and help the SBG officers improve their foreign language knowledge SBG in cooperation with SBGC English language 
teachers should develop a system of qualification improvement courses both in general English and professional terminology meeting the needs of border guards with different levels of English proficiency. At present SBGC implements one qualification improvement course programme aiming at acquisition of Border Guard specific terminology only. The content of the programme is divided into three parts in accordance with the levels descriptors in the SBG rules. Currently there are no any programmes for the border guards who do not know English at all. Such kinds of programmes can be implemented by the SBGC teachers or some private company providing corresponding services. If SBG decides to organise the training in the SBGC it is important to evaluate the possibility to create an additional position of an English teacher in the SBGC and to ensure that the number of planned courses is adequate to a full teacher load based on normative regulations.

5. It is necessary to develop more training resources in English professional terminology, both electronic and paper-based, for border guards and ensure that they are available in all SBG structural units.

6. The SBG and SBGC administration should optimize the process of planning workload for English language teachers, to avoid overlapping of tasks, which can have a negative impact on the quality of tasks fulfilment, including organizing examinations for border guards on a regular basis.

7. In order to ensure the possibility to develop qualitative tests which can provide a valid and credible assessment of SBG officers' levels of knowledge of English professional terminology it is important to provide the SBGC English language teachers with the possibility to improve their skills in tests design, especially creation of tasks, formulation and selection of questions and answers to ensure qualitative assessment.

8. In order to reduce the time teachers spend to create on-line tests and reduce the number of malfunctions of tests, it is important to evaluate the possibility to establish an additional staff position in the SBGC tasked with creation of on-line tests, that is technical adding questions and tasks created by teachers to the on-line training platform.

\section{References}

1. ChatuRVEDI, P.D. (2011) Business Communication: Concepts, Cases, and Applications. Pearson Education Indi. $332 \mathrm{p}$.

2. Common European Framework of Reference for Languages: Learning, Teaching, $\begin{array}{llll}\text { Assessment. } & \text { Retrieved } & \text { August 2020, from }\end{array}$ 
https://www.coe.int/en/web/common-european-framework-referencelanguages.

3. FRONTEX AGENCY. (2017). Common Core Curriculum for Border and Coast Guard Basic Training in the EU. $378 \mathrm{p}$.

4. Regulation (EU) 2016/399 of the European Parliament and of the Council of 9.03.2016 on a Union Code on the rules governing the movement of persons across borders (Schengen Borders Code) Retrieved August 5, 2020, from https://eurlex.europa.eu/legal-content/EN/TXT/?uri=celex\%3A32016R0399.

5. Valsts robežsardzes 26.10.2018. iekšējie noteikumi Nr.30. "Profesionālās terminologijas angḷu valodā zināšanu iegūšanas, uzturēšanas un kontroles kārtība". 